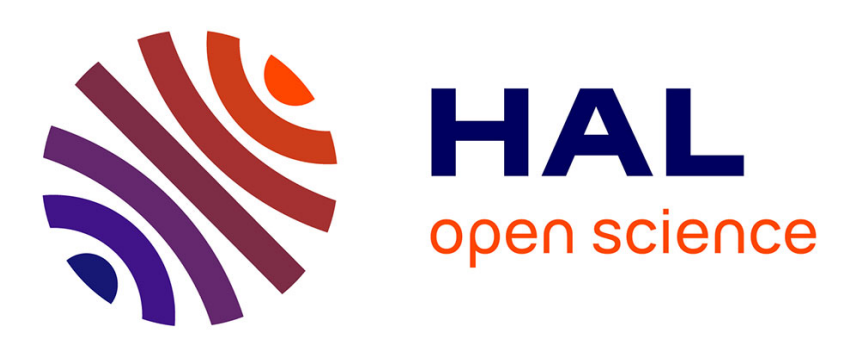

\title{
Optimal Carbon NanoTubes concentration incorporated in mortar and concrete
}

R. Hamzaoui, A. Bennabi, S. Guessasma, M.R. Khelifa, Ali-Nordine Leklou

\section{To cite this version:}

R. Hamzaoui, A. Bennabi, S. Guessasma, M.R. Khelifa, Ali-Nordine Leklou. Optimal Carbon NanoTubes concentration incorporated in mortar and concrete. International Conference on Civil Engineering and Materials (ICCEM 2012), 2012, Paris, France. 10.4028/www.scientific.net/AMR.587.107 . hal-01008618

\section{HAL Id: hal-01008618 https://hal.science/hal-01008618}

Submitted on 23 Oct 2018

HAL is a multi-disciplinary open access archive for the deposit and dissemination of scientific research documents, whether they are published or not. The documents may come from teaching and research institutions in France or abroad, or from public or private research centers.
L'archive ouverte pluridisciplinaire $\mathbf{H A L}$, est destinée au dépôt et à la diffusion de documents scientifiques de niveau recherche, publiés ou non, émanant des établissements d'enseignement et de recherche français ou étrangers, des laboratoires publics ou privés. 


\title{
Optimal Carbon NanoTubes concentration incorporated in mortar and concrete
}

\author{
R. Hamzaoui ${ }^{1, *}$, A. Bennabi ${ }^{1}$, S.Guessasma ${ }^{2}$, M.R. Khelifa ${ }^{3,4}$, N. Leklou ${ }^{5}$ \\ ${ }^{1}$ Université Paris-Est, Institut de Recherche en Constructibilité, ESTP, 28 avenue du Président \\ Wilson- 94234 Cachan, France \\ .$^{2}$ INRA, rue de la Géraudière 44300 Nantes, France \\ ${ }^{3}$ Département LMD Sciences et Techniques, Faculté de Technologie de I'Université de Batna \& \\ Laboratoire Habitat et Environnement de l'Université de Sétif, Algérie \\ ${ }^{4}$ Département Sciences de la Terre et de l'Univers \& Laboratoire Géosciences et Environnement \\ de l'Université de Cergy-Pontoise, France \\ ${ }^{5}$ LUNAM Université, Université de Nantes - IUT Saint-Nazaire, GeM, CNRS UMR 6183, Research \\ Institute in Civil Engineering and Mechanics, France \\ rhamzaoui@adm.estp.fr
}

Keywords: Carbon nanotubes (CNT), mechanical properties, microstructure, mortar, concrete.

Abstract. The mechanical properties and microstructure of modified mortar and concrete using Carbon NanoTubes (CNT) are experimentally studied at 7, 14, 28 and 90 curing days. Part of the formulation, $\mathrm{CNT}$ are dispersed in a liquid solution. Different concentrations ranging from $0.01 \%$ to $0.06 \%$ and $0.003 \%$ up to $0.01 \%$ are used for mortar and concrete, respectively. Mechanical testing of the modified materials reveals that maximum compressive strength is obtained for CNT concentrations close to $0.01 \% \mathrm{wt}$ and $0.003 \% \mathrm{wt}$ for mortar and concrete, respectively. The microstructural characterisation of the modified materials suggests that CNT act as bridges between pores and cracks leading to a reduction in porosity and in turn an increase of compressive strength.

\section{Introduction}

Most crystalline solids are composed of a collection of many small crystals or grains; termed polycrystalline. The term of nanomaterials or nanocrystalline materials (also known as nanostructured or nanophase materials) is used to describe those materials that have a majority of grain size in the typical range from $\sim 1$ to $60 \mathrm{~nm}$. Whether it can be called a revolution or simply evolution, the nanomaterials have received much attention as advanced engineering materials with unique physical, chemical and mechanical properties. Generally nanomaterials have exceptional properties in comparison than to those of coarse-grained ones [1-5]. Since invented by Iijima [6] in 1991, carbon nanotubes have been widely used in a wide spectrum of applications such as in electronics technology, biomaterials design, chemical compounding and multifunctional composites. Carbon nanotubes (CNT) are allotropes of carbon with a cylindrical nanostructure and members of the fullerene structural family [7-8]. One of the most important properties achieved by $\mathrm{CNT}$, in civil engineering applications, is their capability to confer a mechanical reinforcement to cement based structural materials [9-10]. The aim of this work is to study the effect of addition of different amounts of CNT varying from $0.01 \%$ to $0.06 \%$ and from $0.003 \%$ to $0.01 \%$ on the compressive strength and microstructure of mortar and concrete respectively

\section{Materials and methods}

The ordinary Portland cement used in our work is CEMII 32.5R from Colas company and classified in NF P15-301 norm. The carbon nanotubes are delivered by Arkema Company as a liquid solution. The scientific name is Graphistrength CL1-020. Carbon nanotubes multiwall developed by Arkema is an allotrope of carbon and appear as small concentric cylinders of graphite. Table. 1 summarizes CNT properties. Different concentrations namely $0.01 \%, 0.02 \%, 0.03 \%, 0.04 \%, 0.05 \%, 0.06 \%$ for mortar and $0.003 \%, 0.004 \%, 0.006 \%, 0.01 \%$ for concrete are prepared and added to the standard 
formulation like mixing water. The procedure of mortar preparation follows the classified European Standard EN 169-1. The mixed mortar is poured into molds to form prisms of typical dimensions $4 \times 4 \times 16 \mathrm{~cm}$. The mixed concrete is poured into molds to form cylindrical samples with a height of $11 \mathrm{~cm}$ and diameter of $22 \mathrm{~cm}$. The cylinderical concrete samples are finished to have a smooth surface before mechanical testing. Table. 2 summarizes the selected concrete formulation used. Compressive testing for the strength at the 7th, 28th and 90th days is performed using a mechanical testing system (MTS) under constant speed for mortar and hydraulic mechanical testing system (3R) under load control for concrete. Mortar and concrete samples are characterized by Scanning electron microscopy (SEM) (stereo scan 120, Leo 120), with IDIFIX program coupled with energy dispersive spectrometer (EDS).

Table.1 Properties of carbon nanotubes (CNT).

\begin{tabular}{|c|c|}
\hline Electric conductivity & $10^{2}-10^{4}[\mathrm{~s} / \mathrm{cm}]$ \\
\hline PH & 11 \\
\hline Density & $1000-1100\left[\mathrm{~kg} / \mathrm{m}^{3}\right]$ \\
\hline Liquid solution concentration & $2 \%$ wt of CNT \\
\hline Liquid solution color at $20^{\circ} \mathrm{C}$ & Black \\
\hline Liquid solution odor & Slight \\
\hline Liquid solution & Solubility in other solvents \\
\hline
\end{tabular}

Table.2 Modified Concrete formulations used with CNT.

\begin{tabular}{|c|c|c|}
\hline Constituents & $\begin{array}{c}\text { Aggregates } \\
\text { Percentage }\end{array}$ & $\begin{array}{c}\text { Formulation } \\
\text { (en } \mathrm{kg} / \mathrm{m} 3)\end{array}$ \\
\hline $0 / 4$ (Sand) & $38 \%$ & 704.90 \\
\hline $4 / 8$ & $17 \%$ & 315.35 \\
\hline $8 / 16$ & $40 \%$ & 742.00 \\
\hline $16 / 20$ & $5 \%$ & 92.75 \\
\hline Total Aggregates & $100 \%$ & 1855 \\
\hline Cement & & 310 \\
\hline Water & & 1600 \\
\hline
\end{tabular}

\section{Results and discussions}

In order to find an optimal concentration of CNT which exhibits the maximum improvement in compressive strength, different weight percentages of CNT are used. For mortar, test conditions are: $0.01 \mathrm{wt} \%, 0.02 \%, 0.03 \%, 0.06 \%$ whereas for concrete we use rather $0.003 \%, 0.006 \%, 0.01 \%$.

Figure.1a shows the evolution of the mortar compressive strength as function CNT percentage for 90 days. It is observed that the largest compressive strength is found when adding $0.01 \%$ of CNT. Also, it is remarked that the compressive strength for the optimal CNT percentage is $21.2 \%$ higher than the reference mortar. However, further increasing of CNT degrades the compressive strength of mortar.

At 90 days of concrete curing time, the effect of CNT percentage on compressive strength is shown in Figure.1b. Again, the observed maximum compressive strength is reached for a CNT percentage of $0.003 \%$. The gain in compressive strength is $17.65 \%$ with regards to the reference condition. We observe the same trend of strength degradation using a larger amount of CNT. 

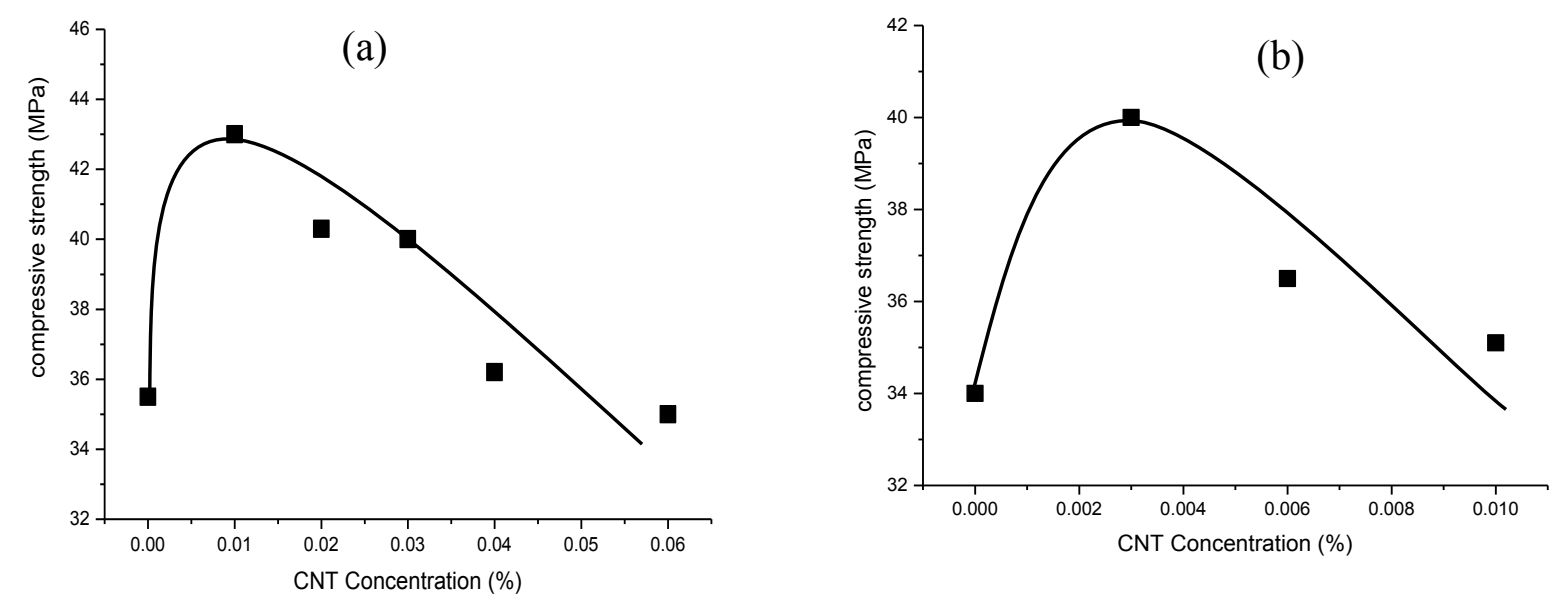

Fig.1 Evolution of the compressive strength as function CNT percentages for 90 days for (a) mortar, (b) concrete

In order to understand the microstructural implications of the observed mechanical behaviour we carried out a morphology analysis using SEM on 90 days concrete samples as presented in Figure 2 (a, b). Figure.2 (a) shows the SEM micrographs of reference concrete for 90 curing days. The microstructure corresponding to the reference condition well highlights the existence of microcrystalline and nearly amorphous phases. The presences of calcium silicate hydrates (C-S-H), calcium hydroxide $(\mathrm{C}-\mathrm{H})$ crystals, voids between the hydrated phases are all evidenced. The calcium silicate hydrates (C-S-H) exist in the form of stand-alone clusters, lapped and joined together by many needle-like hydrates. Furthermore, $\mathrm{CaOH}_{2}$ crystals are distributed among the cement paste. The morphology of concrete with optimal concentration $(0.003 \%)$ of CNT for 90 curing days is shown in Figure.2 (b). We qualitatively observe particular positioning of assemblies of CNT around pores and micro-crackes in a way to provide solid bridges. As the mechanical behaviour is negatively affected by the pore content, we suggest that improvement of strength is due to a reduction of the porosity role. Porosity and mostly microcracks act as preferential sites for stress localisation. Thus, the bridging provided here by CNT increases locally the intrinsic strength of the material as these handle more stress than the matrix.
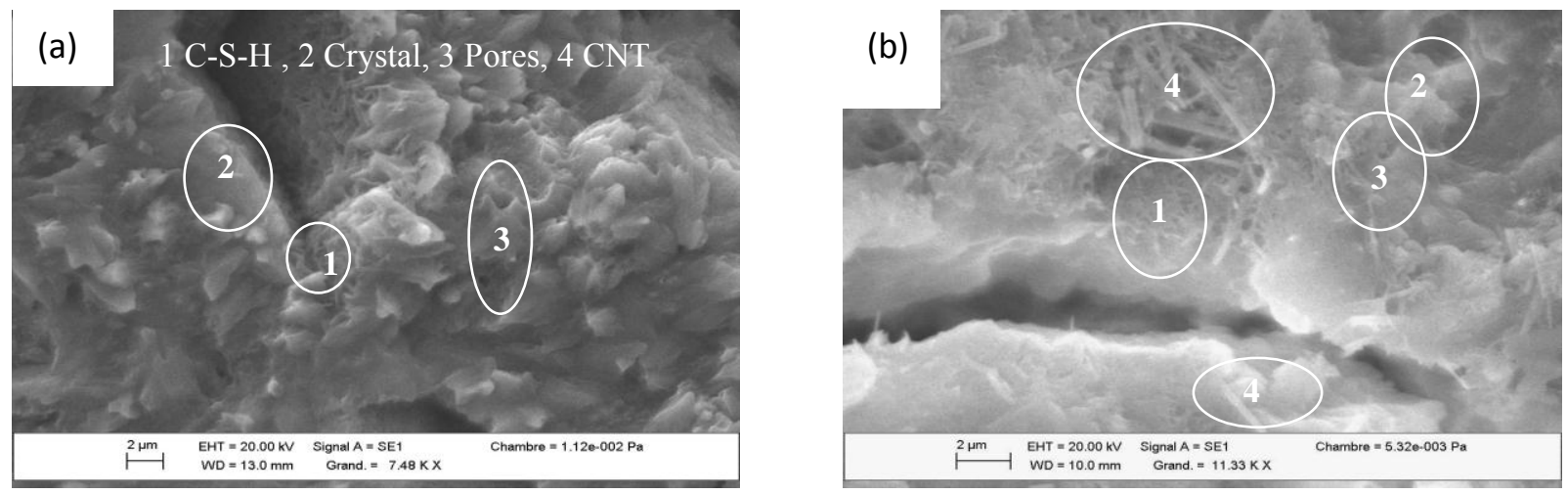

Fig.2 Morphology analysis by scanning electronic microscopy is performed for concrete samples aged of 90 days: (a) reference concrete, (b) concrete $+0.003 \% \mathrm{CNT}$ 


\section{Summary}

The aim of the present research work is to study the mechanical properties and microstructure of different CNT concentrations $0.01 \%, 0.02 \%, 0.03 \%, 0.06 \%$ for mortar and $.003 \%, 0.004 \%$, and $0.006 \%$ for concrete. The following main results are obtained:

1) Optimal concentrations of CNT which give the best compressive strength improvement is $0.01 \% \mathrm{wt}$ and $0.003 \% \mathrm{wt}$ for mortar and concrete, respectively.

2) The factor of compressive strength improvement is 1.2 for mortar and 1.17 for concrete compared to the reference condition free of CNT.

\section{Acknowledgements}

We thank Margarita Walferdein from IRC/ ESTP, Cachan, France, for her technical assistance concerning mechanical measurements. We thank Arkema Company for providing us with the carbon nanotubes in liquid solution.

\section{References}

[1] E. Gaffet, G.Le Caër, "Mechanical processing for Nanomaterials", Encyclopedia of Nanosciences and Nanotechnology. V 5, (2004) 91-129.

[2] M. S. El-Eskandarany, "Mechanical alloying for fabrication of advanced engineering materials", ISBN: 0-8155-1462-X Printed in the United States (2001).

[3] Hui Li, Hui-gang Xiao, Jie Yuan, Jinping Ou, Microstructure of cement mortar with nanoparticles, Composites: Part B 35 (2004) 185-189

[4] R.Hamzaoui, O.Elkedim, N.Fenineche, E.Gaffet and J.Craven, "Structure and magnetic properties of nanocrystalline mechanically alloyed $\mathrm{Fe}-10 \% \mathrm{Ni}$ and $\mathrm{Fe}-20 \% \mathrm{Ni}$ ". Materials Sciences and Engineering A 360 (2003) 299-305.

[5] S. Tria, O.Elkedim, R. Hamzaoui, X. Guo, F. Bernard, N. Millot and O.Rapaud "Deposition and characterization of cold sprayed nanocrystalline NiTi” Powder Technology Vol210, (2011) 181188.

[6] S. Iijiman, "Helical microtubes of graphitic carbon", Nature 354(7), (1991), 8-56.

[7] M. S .Dresselhaus, G. Dresselhaus, Ph. Avouris, "Carbon nanotubes synthesis, structure, properties and applications", ISSN print edition: 0303-4216, Spriner-Verlag Berlin Heideberge, printed in Germany (2001).

[8] S. Reich, C. Thomsen, J. Maultzsch, "Carbon nanotubes, basic concepts and physical properties", $1^{\text {st }}$ edition, WILEY-VCH Verlag GmbH\&Co.KGaH, (2004)

[9] Geng Ying Li, Pei Ming Wang, Xiaohua Zhao, Mechanical behavior and microstructure of cement composites incorporating surface-treated multi-walled carbon nanotubes, Carbon 43 (2005) $1239-1245$.

[10] Pudov P.A, Pislegina A.V, Lshnikova A.A Pervushin, Yakovlev G.I, Challenges in carbon nanotube dispersion during the modification of fine cement concretes. International conference on nano-Technology for green and sustainable construction, Cairo-Egypt 14-17 March (2010). 